\title{
Restriction Fragment Length Polymorphism Analysis Reveals High Levels of Genetic Divergence Among the Light Organ Symbionts of Flashlight Fish
}

\author{
CONNIE J. WOLFE AND MARGO G. HAYGOOD \\ Scripps Institution of Oceanography, University of California, San Diego, California 92093
}

\begin{abstract}
Restriction fragment length polymorphisms within the lux and $16 \mathrm{~S}$ ribosomal RNA gene regions were used to compare unculturable bacterial light organ symbionts of several anomalopid fish species. The method of Nei and Li (1979) was used to calculate phylogenetic distance from the patterns of restriction fragment lengths of the $l u x \mathrm{~A}$ and $16 \mathrm{~S}$ rRNA regions. Phylogenetic trees constructed from each distance matrix (luxA and 16S rDNA data) have similar branching orders. The levels of divergence among the symbionts, relative to other culturable luminous bacteria, suggests that the symbionts differ at the level of species among host fish genera. Symbiont relatedness and host geographic location do not seem to be correlated, and the symbionts do not appear to be strains of common, free-living, luminous bacteria. In addition, the small number of hybridizing fragments within the $16 \mathrm{~S}$ rRNA region of the symbionts, compared with that of the free-living species, suggests a decrease in copy number of rRNA operons relative to free-living species. At this level of investigation, the symbiont phylogeny is consistent with the proposed phylogeny of the host fish family and suggests that each symbiont strain coevolved with its host fish species.
\end{abstract}

\section{Introduction}

Members of the teleost fish family Anomalopidae harbor luminous bacterial symbionts in specialized light organs, located under each eye. Light is produced continuously by the bacteria through the action of bacterial luciferase; but depending on the species, the light may be occluded, either by rotation of the entire light organ, or by a shutter mechanism (Kessel, 1977; Leisman et al., 1980; Johnson and Rosenblatt, 1988). The four genera of

Received 20 November 1990; acceptcd 18 March 1991. anomalopid fishes contain five species: Anomalops katoptron, Photoblepharon palpebratus, Photoblepharon steinitzi, Kryptophanaron alfredi, and Phthanophaneron harveyi. Evidence from comparative morphology and biogeography suggests the following familial phylogeny (Johnson and Rosenblatt, 1988). The anomalopids appear to have branched off of the Trachithyid lineage during the Cretaceous period. The genus Anomalops probably diverged later in the Cretaceous and is radically different from the other genera. Phthanophaneron diverged in the Miocene with Kryptophanaron, and Photoblepharon diverged most recently, in the Pliocene.

Luminous bacterial symbionts in several other families of fishes have been cultured. In these instances, a single species of symbiont is associated with an entire family of host fish. These bacteria belong to species that have also been isolated directly from seawater, and the juvenile host may acquire its symbionts from the surrounding water at each generation (Ruby and Nealson, 1976; Fitzgerald, 1977; Reichelt et al., 1977; Leis and Bullock, 1986; Wei and Young, 1989). Other light organ symbioses, in ceratioid fishes and pyrosomes, contain unculturable symbionts, and the identity of the symbionts is unknown in those cases. The anomalopid symbionts have, as yet, defied all of our attempts to culture them in laboratory media. Our inability to culture the symbionts, combined with the extensive morphological adaptations of the host fish, suggest an obligate symbiosis in which the bacteria may have coevolved with the fish host.

We have compared the symbionts in four species of anomalopid fish by analyzing restriction fragment length polymorphisms (RFLPs) of fragments containing either the luciferase structural genes (luxAB), or the $16 \mathrm{~S}$ ribosomal RNA genes. RFLPs of other structural genes have frequently been used to compare species and populations of bacteria (Stanley et al., 1985; Franche and Cohen-Ba- 
zire, 1987; Denny et al., 1988; Lindblad et al., 1989). Ribosomal RNA genes are very conserved, and comparisons of rRNA gene restriction patterns had previously been used to differentiate between species, as well as subspecies, of bacteria (Gottlieb and Rudner, 1985; Grimont and Grimont, 1986; Saunders et al., 1988; Stull et al., 1988; Buyser et al., 1989). Our goal was to analyze both gene regions to determine: (1) whether the symbionts are the same species in all of the anomalopids or are specific to fish species, genus, or geographic location; (2) the interrelationships of the symbionts compared with the phylogeny of the host fish, to support or refute the coevolution hypothesis; and (3) the broader phylogenetic affiliations of the symbionts within the luminous bacteria.

\section{Materials and Methods}

\section{Bacterial strains}

Bacterial strains used in this study are described in Table I. The free-living luminescent strains were grown in complex scawater broth (SWC: Ruby and Nealson, 1978) at $25^{\circ} \mathrm{C}$.

\section{Fish collection}

Fish were hand-collected by SCUBA divers in the locations shown in Table I. Samples of four species of fish were obtained, including two species (A. katoptron and $P$. palpebratus) from two genera collected at the same location in Papua New Guinea. Both specimens of Photoblepharon from Papua New Guinea would be identified as $P$. palpebratus on the criteria given by McCosker and Rosenblatt (1986). The two specimens are similar in meristics and overall morphology, but differ in coloration. $P$. palpebratus \#1 is dark, has the white area on the opercle characteristic of the species, and the white reflecting scales and fin edgings shared with $P$. steinitzi. $P$. palpebratus \#2 is grey, and lacks contrasted white areas on the body and fins (R. H. Rosenblatt, pers. comm.). The P. steinitzi specimen was obtained at Eilat, Israel, and is thus virtually certainly $P$. steinitzi, although the specimen is no longer available for positive identification.

\section{DNA preparation}

Samples of DNA were prepared from single, entire, fish light organs as in Haygood and Cohn (1986). Total DNA yield per light organ ranged from 5 to $63 \mu \mathrm{g}$ of DNA. DNA from the other luminous bacterial strains was isolated by the method of Ditta et al. (1980). DNA concentration was determined spectrophotometrically by absorbance at $260 \mathrm{~nm}$.

\section{DNA digestion, electrophoresis, and hybridization}

DNA samples were digested with the following enzymes: HpaI, ScaI, BglII, KpnI, PstI, ClaI, HincII and $S p h \mathrm{I}$ for lux RFLP analysis; and EcoRI, BglII, HindIII and $N c i$ for the $16 \mathrm{~S}$ rRNA gene comparison. Each digest consisted of about $200 \mathrm{ng}$ of DNA. The digests were separated by $0.8 \%$ agarose gel electrophoresis in $40 \mathrm{~m} M$ Tris acetate/ $1 \mathrm{~m} M$ EDTA pH 8.0. The agarose gels were dried at $60^{\circ} \mathrm{C}$, denatured, neutralized (Tsao et al., 1983), and prehybridized at $60^{\circ} \mathrm{C}$ in $6 \times \mathrm{SSC}$ (sodium chloride/sodium citrate; Maniatis et al., 1982), $2.5 \mathrm{mM}$ EDTA, 200 $\mu \mathrm{g} / \mathrm{ml}$ denatured salmon sperm DNA and $0.5 \mathrm{mg} / \mathrm{ml}$ dried milk. In previous work, the $K$. alfredi symbiont lux region was cloned into pDR720 (Haygood and Cohn, 1986). A $1.73 \mathrm{~kb} \mathrm{Hpal} / \mathrm{KpnI}$ fragment containing $l u x \mathrm{~A}$ and half of

Table I

Origins of DNA samples

\begin{tabular}{|c|c|c|c|c|}
\hline Bacterial species & Strain & Host & Collection site & Source or reference \\
\hline Vibrio harvevi & B392 & NA & Unknown & Reichelt and Baumann, 1973 \\
\hline Vibrio harveyi & BB? & NA & Sargasso Sea & Belas et al., 1984 \\
\hline Vibrio orientalis \#1 & ATCC \#33933 & NA & Yellow Sea & Yang et al., 1983 \\
\hline Vibrio orientalis \#2 & ATCC $\# 33934$ & NA & Yellow Sea & Yang et al., 1983 \\
\hline Vibrio fischeri & B61 & $\mathrm{NA}$ & $20^{\circ} 30^{\prime}$ latitude, $157^{\circ} 30^{\prime}$ longitude & Baumann et al., 1971 \\
\hline Vibrio fischeri & MJ1 & Monocentris japonicus & 50 miles southeast of Tokyo, Japan & Ruby and Nealson, 1976 \\
\hline \multicolumn{5}{|l|}{ Photobacterium } \\
\hline phosphoreum & NZ11D & Nezumia aequalis & $28^{\circ} 42^{\prime} \mathrm{N}, 13^{\circ} 8^{\prime} \mathrm{W} ; 906$ to $936 \mathrm{~m}$ depth & Ruby and Morin, 1978 \\
\hline NA & $\mathrm{NA}$ & Kyptophanaron alfredi \# $\mathrm{I}$ & La Parguera, Puerto Rico & Haygood and Cohn, 1986 \\
\hline NA & NA & Kryptophanaron alfredi $\# 16$ & Roatan, Honduras & This study \\
\hline NA & NA & Anomalops katoptron \#1 & Port Moreshy, Papua New Guinea & This study \\
\hline NA & $\mathrm{NA}$ & Anomalops kaptoptron \#2 & Madang, Papua New Guinea & This study \\
\hline NA & NA & Photoblepharon palpebratus \#1 & Port Moresby, Papua New Guinea & This study \\
\hline NA & NA & Photoblepharon palpebratus \#2 & Port Moresby, Papua New Guinea & This study \\
\hline NA & NA & Photoblepharon steinitzi & Eilat, Israel & This study \\
\hline
\end{tabular}

NA, not applicable. 
Table II

Pairwise comparisons of the percentage conserved fragments and the genetic distances (see Materials and Methods) within the lux gene regions of Vibrio harveyi and the anomalopid symbionts

\begin{tabular}{|c|c|c|c|c|c|}
\hline \multirow[b]{2}{*}{ Strain } & \multicolumn{5}{|c|}{ Strain } \\
\hline & $\begin{array}{l}\text { V. harveyi } \\
\text { B392 }\end{array}$ & $\begin{array}{c}\text { A. katoptron } \\
\# 1\end{array}$ & $\begin{array}{c}\text { K. alfredi } \\
\# 1\end{array}$ & $\begin{array}{c}\text { P. palpebratus } \\
\# 2\end{array}$ & P. steinitzi \\
\hline Vibrio harveyi $\mathrm{B} 392$ & & 16.0 & $>17.8$ & $>16.0$ & $>16.8$ \\
\hline Anomalops katoptron \#1 & 8.3 & & $>16.8$ & $>14.7$ & $>15.7$ \\
\hline Kyptophanaron alfredi $\# 1$ & $<6.5$ & $<7.4$ & & 12.0 & 17.6 \\
\hline Photoblepharon palpebratus \#2 & $<8.3$ & $<10.0$ & 14.8 & & 10.9 \\
\hline P. steinitzi & $<7.4$ & $<8.7$ & 6.7 & 17.4 & \\
\hline
\end{tabular}

The lower values are the percentage of conserved fragments and the upper values the estimated genetic distances (multiplied by 100 ). In cases where no fragments were conserved, values are listed as being less than the minimum conservation which can be calculated from the total number of observed fragments or greater than the minimum calculable genetic distance.

lux $\mathrm{B}$ was isolated from the plasmid by $0.8 \%$ low melting point agarose electrophoresis. Plasmid pNO1301 (Gourse et al., 1982; Jinks-Robertson et al., 1983) carrying rRNA genes of Escherichia coli was digested with HindIII, and a $568 \mathrm{bp}$ fragment within the $16 \mathrm{~S}$ rRNA gene was isolated on a $0.8 \%$ low melting point agarose gel. The fragments were cut out of the gel, the gel slices were melted, and this material was used directly with the Pharmacia random priming kit to obtain $\left[\mathrm{a}^{32} \mathrm{P}\right] \mathrm{dCTP}$ labeled probe. Probes were added to each prehybridized gel and incubated for $16 \mathrm{~h}$ at $60^{\circ} \mathrm{C}$. After hybridization, the gels were washed in $1 \times \mathrm{SSC}, 0.1 \% \mathrm{SDS}$ at $60^{\circ} \mathrm{C}$, and exposed to X-ray film. Each gel was exposed for several different intervals to ensure the detection of all hybridization fragments. Control experiments indicated that there was no hybridization of the lux probe to $E$. coli genomic DNA, or of the $E$. coli $16 \mathrm{~S}$ probe to flashlight fish genomic DNA under these conditions.

\section{Estimation of sequence divergence}

An estimation of sequence divergence (number of nucleotide substitutions per site) was calculated from the fraction of conserved hybridizing fragments for each pair of DNAs (Nei and Li, 1979; Nei, 1987). This estimation is applicable to closely related DNA sequences and is based on the assumption that fragment changes occur due to base substitutions within the restriction sites, rather than to major deletions or rearrangements. The sequence divergence within and surrounding the luxA gene was estimated for the four symbiont species and Vibrio harveyi by comparing the hybridization patterns obtained from restriction digests hybridized to the $K$. alfredi symbiont lux probe. All of the restriction enzymes used in the lux analysis recognized $6 \mathrm{bp}$; thus the data from all digests were additive and analyzed together (Nei and Li, 1979; Nei, 1987). Divergence within and around the 16S rRNA genes of the symbionts and several strains of free-living luminous bacteria was determined by analysis of common hybridizing fragments to the $568 \mathrm{bp}$ probe. The $16 \mathrm{~S}$ rRNA data from HindIII, $B g l \mathrm{II}$, and $E c o R$ I enzyme digestions were additive and were analyzed together; the data from $\mathrm{Ncil}$ digestion were analyzed separately because $\mathrm{Ncil}$ recognizes 5 bp rather than 6 (Nei and Li, 1979; Nei, 1987). Data for each enzyme within both analyses were also analyzed individually and compared with the additive data set. When no common hybridizing fragments were observed between a pair, the fraction of conserved hybridizing fragments was given as less than the smallest calculable fraction, and the genetic distance between the pair was given as greater than the maximum calculable distance. All resulting distance matrices were analyzed using the Fitch-Margoliash method to form trees [program FITCH, from the Phylogenetic Inference Package (PHYLIP) version 3.2, by Dr. J. Felsenstein]. Each group of tree files was read by the CONSENSE program (also from PHYLIP), and consensus trees were generated and compared.

\section{Results}

\section{Comparison of RFLPS within the luxAB gene region}

The percentage of conserved fragments among $V$. har veyi and the various anomalopid symbionts was calculated from pair-wise comparisons of fractions of conserved hybridizing fragments (Table II, lower left). The $K$. alfredi symbiont lux probe hybridized to restriction fragments of each of the symbionts, but the hybridization patterns showed little conservation (Fig. 1). In fact, no enzyme of the eight tested produced a hybridization fragment conserved among all of the symbionts. Three of the enzymes ( $B g / \mathrm{II}, \mathrm{HincII}$ and $H p a \mathrm{I}$ ) revealed no conserved hybridizing fragments between the symbionts, or between any symbiont and $V$. harveyi B392. The Photoblepharon palpebratus and $P$. steinitzi symbionts (P. p. \#1 and P. s. \#1) 


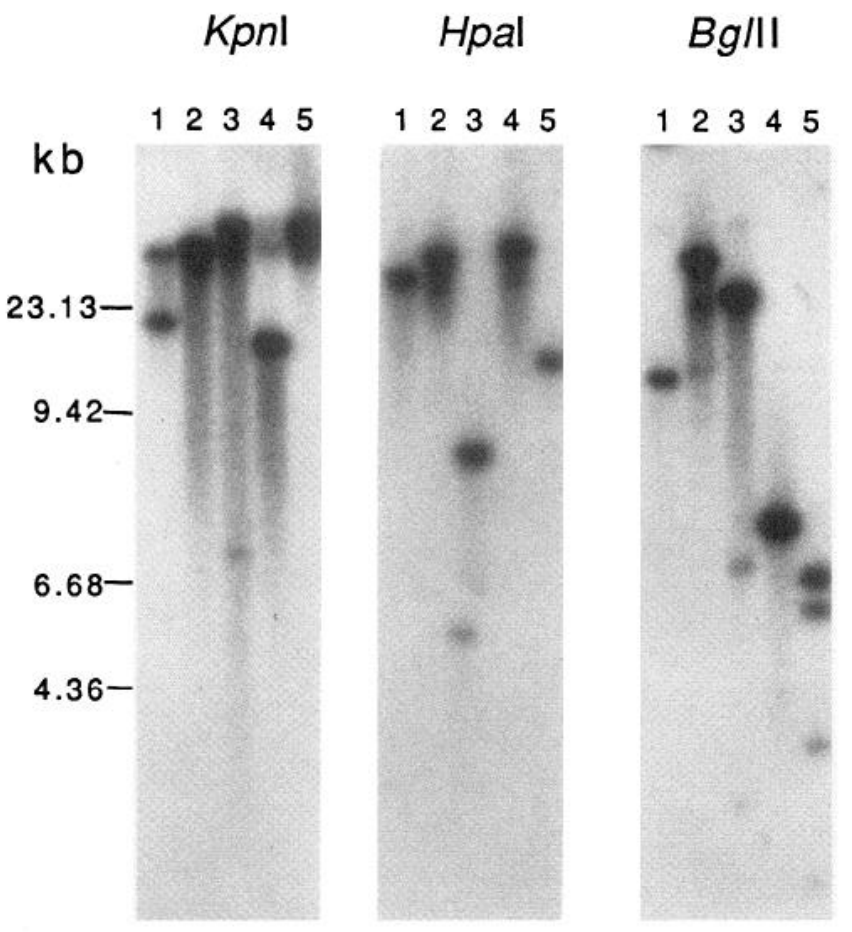

Figure 1. Autoradiogram obtained from hybridization of the ${ }^{32} \mathrm{P}$ labeled $1.73 \mathrm{~kb}$ lux probe to DNA extracted from Vibrio harveyi B392 (1) and the light organs of Anomalops katoptron \#1 (2), Kryptophanaron alfredi \#1 (3), Photoblepharon palpebratus \#2 (4), and Photoblepharon steinitzi (5). DNA was digested with $K p n I, H p a I$ and $B g l \mathrm{II}$.

are most similar, with a distance of 0.109 . The A. katoptron specimen has no conserved hybridizing fragments with any of the other anomalopid symbionts; thus the calculated distances are underestimates of an unknown distance. The divergence (d) among symbionts and between symbionts and $V$. harveyi ranges from 0.109 to $>0.178$ when calculated with Nei and Li's method (Table II, upper right). Values for $d$ have been multiplied by 100 in Table II, to facilitate easy visual comparison. The consensus tree is shown in Figure 2.

\section{Comparison of RFLPS detected by the 16S rRNA gene probe}

In DNA digests of every bacterial strain tested, the 568 bp 16S rRNA gene probe hybridized with between 1 and 12 restriction fragments generated by enzymes with sixbase-pair recognition sequences (Fig. 3). Digestion of the $V$. harveyi strains generated the highest number of hybridizing fragments ( $\sim 9 /$ digest), while digestion of the symbiont DNAs, particularly from Anomalops and Kryptophanaron, resulted in fewer hybridizing fragments $(\sim 2 /$ digest). In both the lux and $16 \mathrm{~S}$ comparisons, the number of hybridizing fragments indicates that a single symbiont inhabits each light organ or that any additional symbionts are present at undetectable levels. The number of hybrid- izing fragments in the lux comparisons are consistent with the presence of a single copy of the lux genes, in both the symbionts and the culturable strain. In the $16 \mathrm{~S}$ comparisons, the low number of symbiont fragments indicates that a mixed symbiont culture is unlikely. As shown by the fractions of conserved hybridizing fragments (Table III, lower left), the $16 \mathrm{~S}$ probe generally yielded a higher number of conserved fragments than the lux probe. Distances calculated from hybridization patterns among culturable species range from 0.062 to 0.216 , with a mean of $0.113 \pm 0.040$ (the standard deviation was calculated from values in Table III). As in Table II, the $d$ values shown in Table III have been multiplied by 100 to ease visual comparison. The symbionts differ from the culturable species with distances ranging from 0.099 to $>0.180$. Distances among symbionts from fish of different genera range from $>0.117$ to $>0.151$, contrasting strongly with the level of difference seen between strains of culturable species $(0.029 \pm 0.021)$. Thus, the symbionts in this family do not appear to be members of a single species.

In two instances, a strain-level relationship was seen between symbionts. The two specimens of $A$. katoptron were indistinguishable, and distance values for symbiont DNAs from P. steinitzi and $P$. palpebratus \#1 are also close, with a calculated distance of 0.023 . Thus, because these values are within the range that we have seen when comparing strains of the same species of Vibrio (Table III), these two symbiont strains should be considered as

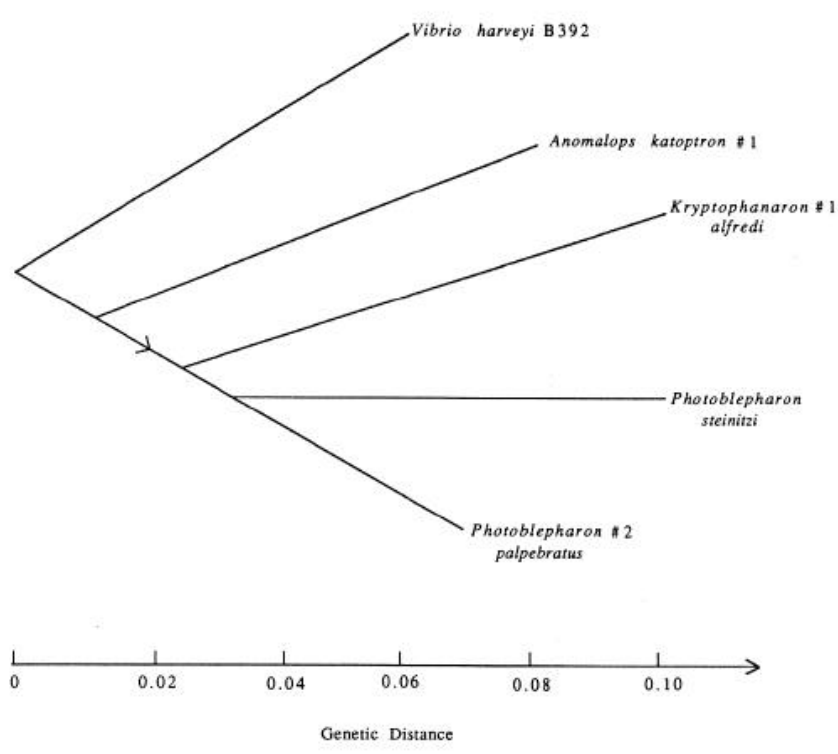

Figure 2. Phylogenetic tree for anomalopid symbiont strains and Vibrio harveyi constructed from the lux region genetic distance data in Table II. The tree is a majority rule consensus tree derived from the CONSENSE program of PHYLIP (see Materials and Methods). Branch lengths were obtained from the data in Table II using the FITCH program of PHYLIP. The arrow indicates that the following branch lengths are minimum estimates; there were few or no conserved hybridizing fragments between this group of strains and the others compared. 
EcoRI

12334566788910111213

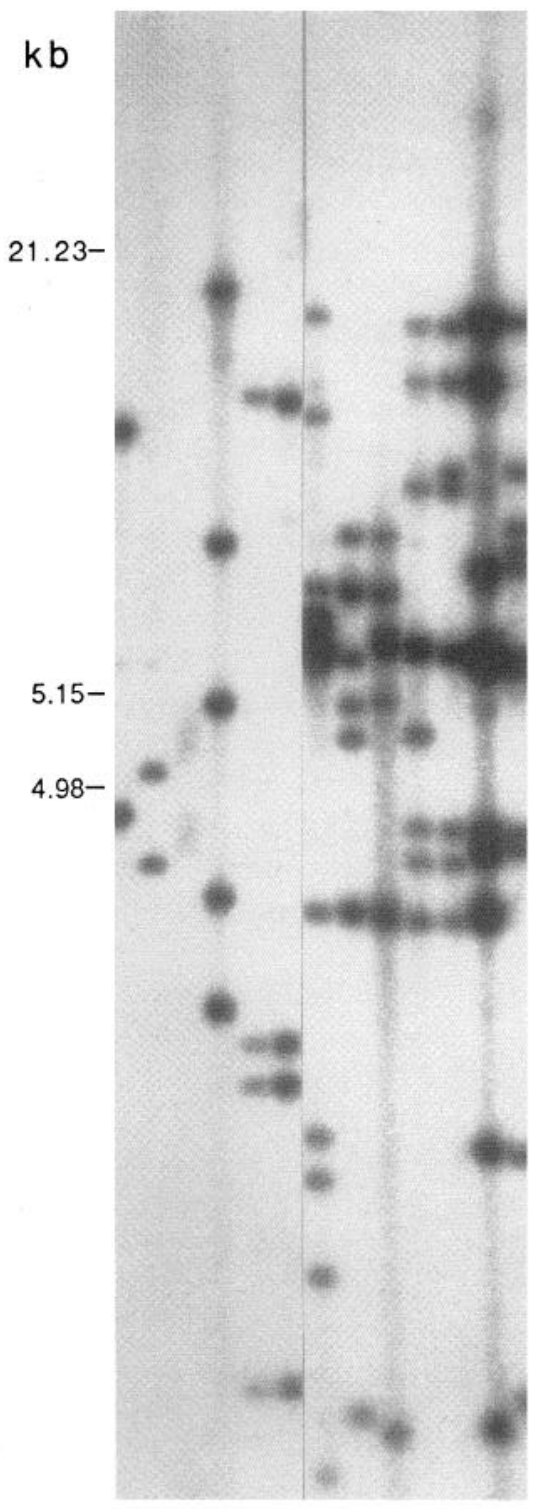

Bg/ll

1233456788910111213

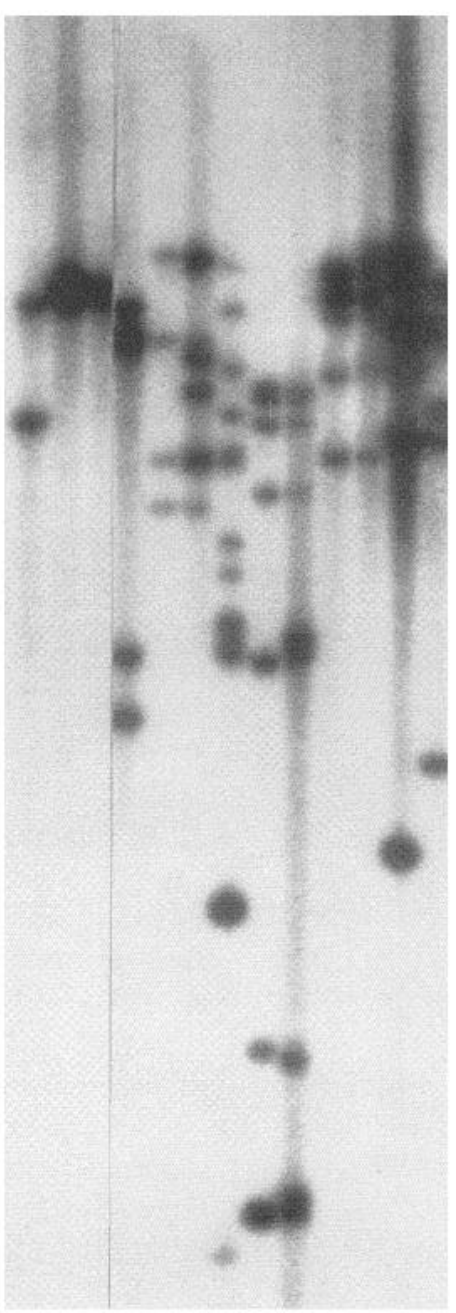

Hindll

122344567789910111213

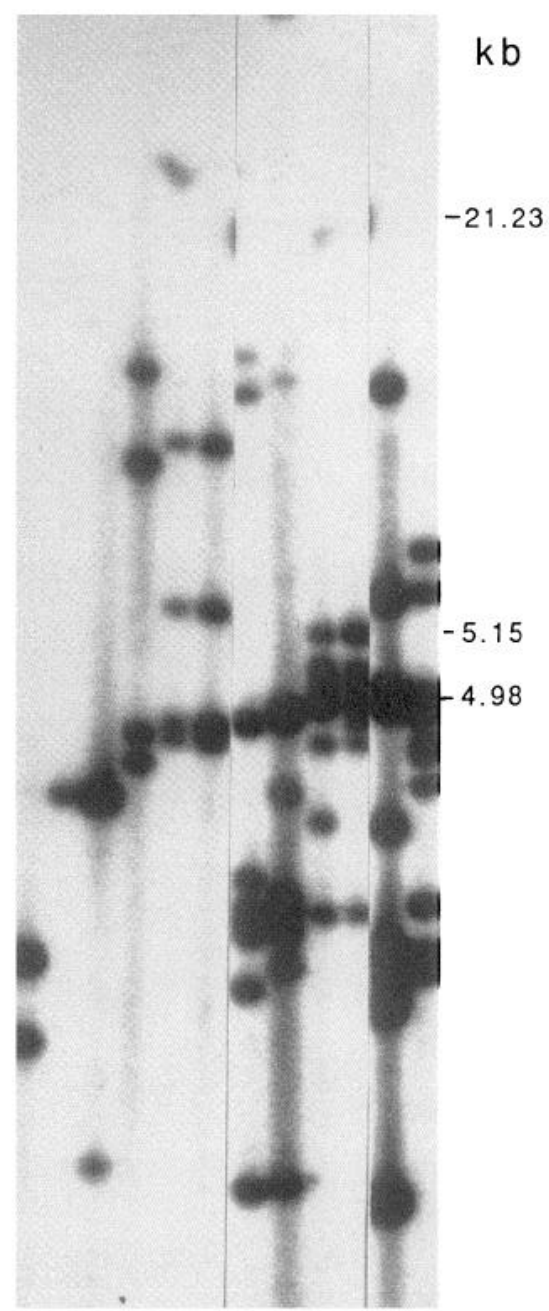

Figure 3. Autoradiogram obtained from hybridization of the ${ }^{32} \mathrm{P}$-labeled $16 \mathrm{~S}$ rRNA gene probe to DNA extracted from the light organs of Kryptophanaron alfredi \#16 (1), Anomalops katoptron \#2 (2), Anomalops katoptron \#1 (3), Photoblepharon palpebratus \#2 (4), Photoblepharon palpebratus \#1 (5), Photoblepharon steinitzi (6), and from laboratory cultures of Vibrio fischeri B61 (7), Vibrio fischeri MJ1 (8), Vibrio orientalis \#2 (9), Vibrio orientalis \#1 (10), Vibrio harveyi BB7 (11), and Vibrio harveyi B392 (12). DNA was digested with EcoRI, BglII and HindIII. Molecular weight markers are the same for both EcoRI and BglII.

belonging to the same species. All of the Photoblepharon symbionts (P. p. \#1, P. p. \#2, and P. s. \#1) are more similar to each other than to $K$. alfredi and A. katoptron. However, two samples from different individuals of $P$. palpebratus (P. p. \#1 and P. p. \#2) collected in the same geographic location showed considerable differences in their restriction patterns. Moreover, one P. palpebratus sample (P. p. $\# 1)$ is more closely related to the sample of $P$. steinitzi than to the other P. palpebratus sample (P. p. \#2). The degree of difference between the symbionts of the $P$. palpebratus specimens is even more anomalous when compared to the total conservation of restriction fragments from the DNA of two Anomalops specimens from different geographic locations. The possibility of inadvertent exchange of samples was investigated and it does not appear to have occurred; the experiments were repeated with 


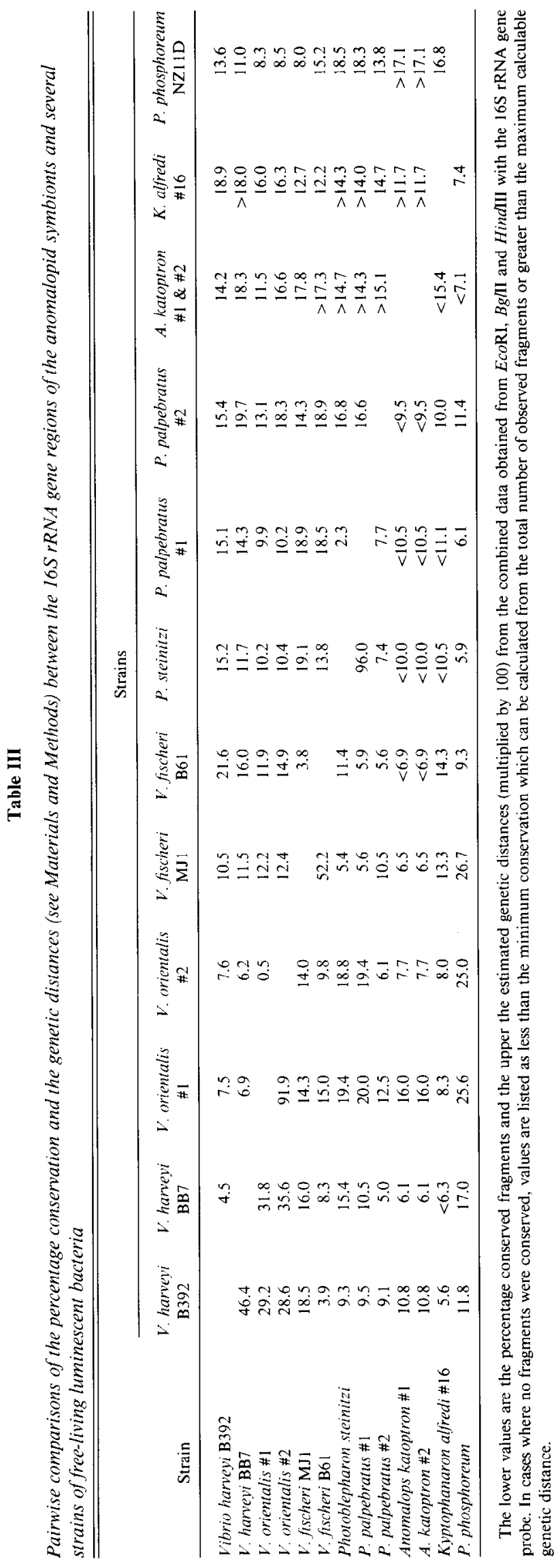

identical results. The consensus tree generated is shown in Figure 4.

\section{Discussion}

Our data indicate that the bacterial symbionts differ dramatically within the family Anomalopidae. Based on RFLP analysis within the lux gene region, the symbionts from different genera are almost as different from one another as the Kryptophanaron symbiont is from V. harveyi. Comparison of the symbiont restriction patterns with those of known species of luminous bacteria within the $16 \mathrm{~S}$ rRNA gene region strongly supports the conclusion, drawn from the lux data, that the symbionts differ at greater than strain level between genera within the family Anomalopidae.

In other light organ symbioses, in which the symbionts have been cultured, all members of the fish family contain the same bacterial species. RFLP analysis supports this assertion for Photobacterium phosphoreum, a bacterial species that inhabits light organs of several families of fishcs. The genetic distances between three strains of $P$. phosphoreum from two species of opisthoproctid fishes (Opisthoproctus grimaldii and Opisthoproctus soleatus) and $P$. phosphoreum NZ11D, a symbiont from a macrourid fish, were determined using the same 16S RFLP analysis method, and ranged from 0.002 to 0.006 (data not shown). The small genetic distances observed for the opisthoproctid symbionts contrast greatly with the large differences observed among the anomalopid symbionts.

Clearly, the anomalopids do not appear to host a single species. Symbionts from different anomalopid genera differ at least as much as species of culturable luminous bacteria. In the $16 \mathrm{~S}$ rRNA analysis, the observed distances between the anomalopid symbionts are considerably greater than the distance between $V$. harveyi and $V$. orientalis, approaching the distance between $V$. harveyi and $V$. fischeri, two highly divergent members of the genus Vibrio (Baumann et al., 1980). In contrast, there is a high level of conservation among strains of characterized Vibrio species, even among the frec-living and monocentrid symbiont strains of $V$. fischeri from different locations (strains B61 and MJ1, Table I and Fig. 4).

Within the anomalopid family, equivalent strain levels of similarity are found only within genera, in two of the three samples from the genus Photoblepharon (P. p. \#1 and P. s. \#1) and the samples from different specimens of $A$. katoptron. In addition, we recently collected several specimens of Kryptophanaron alfredi from Roatan, Honduras, and compared five light organ samples, using the $16 \mathrm{~S}$ probe and the same restriction enzymes previously used in this study. The specimens were indistinguishable, with all fragments conserved. Thus, although we do not have additional samples of each fish species within the anomalopid family, it seems likely that symbionts within 

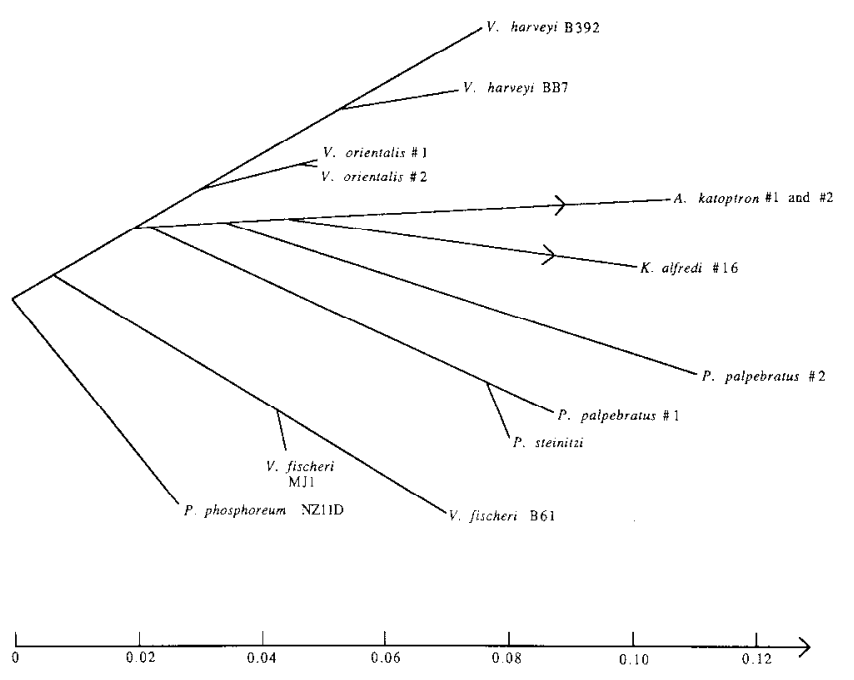

Generic Distance

Figure 4. Phylogenetic tree for anomalopid symbionts and several free-living luminous bacteria constructed from the 16S rRNA gene region genetic distance data in Table III. The tree is a majority rule consensus tree derived from the CONSENSE program of PHYLIP. Branch lengths were obtained from the data in Table III using the FITCH program of PHYLIP. Arrows on two of the branches indicate that the branch lengths are minimum estimates; there were few or no conserved hybridizing fragments between these strains and the others compared.

each host species comprise a single species. The anomalous result with $P$. palpebratus \#2 is discussed below.

The observed diversity among symbionts within the family Anomalopidae is not associated with geographical location, and this might be expected if the symbionts engage in genetic exchange with bacterial populations in the environment. DNA from specimens of $P$. palpebratus and A. katoptron collected from the same location in Papua New Guinea are no more similar to each other than each is to the $K$. alfredi symbiont from the Caribbean. In fact, they arc considerably less similar than the symbionts from Photoblepharon specimens from the Red Sea and Papua New Guinea (P. p. \#1 and P. s. \#1). In addition, symbionts from two samples of $A$. katoptron, collected from different locations in Papua New Guinea ( $\sim 800$ miles apart) appear identical within the 16S rRNA gene region. Thus, the genetic similarity of symbionts seems to correlate more with host phylogeny than geographic location.

Precise comparisons of the symbiont branching order to the proposed evolutionary history of the host fish are difficult because the branch lengths are very rough estimates. However, the branching order, is similar in both analyses and is consistent with that of the fish host (Johnson and Rosenblatt, 1988). These highly conservative estimates of distance indicate that the Anomalops symbiont differs from the other symbionts at the specific, and possibly the generic, level. Anomalops is very different from the other genera in the family Anomalopidae and is thought to have diverged from the ancestral lineage at least 60 million years before the divergence of Kryptophanaron and Photoblepharon ( $<5$ million years ago). The Kryptophanaron symbiont also differs from the Photoblepharon symbionts, but does share some conserved hybridizing fragments with Photoblepharon symbionts in both the lux and rRNA analyses. These data suggest that the symbionts may have coevolved with the host fish. However, the divergence between the two P. palpebratus samples raises the possibility that the apparent correspondence between symbiont and host trees could disappear when more samples are examined; i.e., that extreme divergence may occur in symbionts within host species as well as between host genera. However, this hypothesis is not supported by the identity observed between the two Anomalops samples from different locations, the similarity of $P$. palpebratus \#1 and $P$. steinitzi, and our comparison of five $K$. alfredi samples. Equally likely alternatives are that (1) the genus Photoblepharon is more complex than current systematics would suggest, and that more than one type of Photoblepharon may occur at our collection site (see Materials and Methods) or (2) a gene rearrangement in the $P$. palpebratus $\# 2$ symbiont relative to the other anomalopid symbionts could give an overestimate of genetic distance. Unfortunately, the additional specimens needed to resolve this anomaly are not currently available and will be difficult to obtain. Further study of both the systematics of Photoblepharon and the genetic relatedness of the symbionts is required.

Another interesting aspect of the 16S rRNA RFLP analysis is the variation in number of hybridizing restriction fragments between symbiont and free-living bacterial DNA. In all cases, the symbionts show fewer hybridizing fragments to the $16 \mathrm{~S}$ probe than the free-living strains. The low number of hybridizing fragments revealed in this study suggests the presence of a bacterial monoculture in the light organ. In addition, these data could indicate a difference in copy number of the rRNA genes; i.e., the symbionts have a lower number of operons than the freeliving luminescent strains. Similar studies on pea-aphid endosymbionts revealed that the endosymbionts have only a single copy of the rRNA operon, while related free-living organisms have several (Unterman and Baumann, 1990). Restriction fragment analyses of mycobacteria 1 DNA have shown that the number of rRNA copies correlates with growth rate, i.e., slow growing species have fewer copies of the rRNA operon than those growing more rapidly (Bercovier et al., 1986; Suzuki et al., 1987). Previous studies of anomalopids suggested that symbionts in the light organ have slow growth rates [doubling times of 823 hours; (Haygood et al., 1984)]. A reduced rRNA operon copy number in the anomalopid symbionts may represent a permanent adaptation to light organ conditions, such that the growth rate is inherently low in the anomalopid symbionts. 
The taxonomic identity of the anomalopid symbionts remains unknown. None of the luminous species included in the $16 \mathrm{~S}$ rRN $\Lambda$ region analysis appear to be the same species as the symbionts, which fall somewhere between $V$. orientalis and $V$. fischeri. The $16 \mathrm{~S}$ rRNA region analysis suggests that the symbionts are more closely related to $V$. orientalis than to $V$. harveyi. LuxA nucleotide sequence data for $V$. harveyi, $V$. fischeri, and the Kryptophanaron alfredi symbiont reveal a closer relationship between $V$. harveyi and the $K$. alfredi symbiont (75\% identity) than between the symbiont and $V$. fischeri [63\% (Haygood, 1990)]. This relationship is not observed in the $16 \mathrm{~S}$ data, which indicate that the symbionts are equally related to both $V$. harveyi and $V$. fischeri. This discrepancy could indicate that the similarity of the symbiont with $V$. harveyi is found only within the $l u x$ region and is not distinguishable at the rRNA level.

The RFLP approach has some limitations, due to errors in the estimation of distance. These errors result from small, undetected fragments, or fragments of slightly different lengths, that are indistinguishable at the level of gel electrophoresis. The major virtue of the RFLP approach is that many samples can be analyzed directly and simultaneously. The calculations of genetic distance are based on assumptions about the substitution rate and frequency of the four nucleotides within a sequence (Nei, 1987). The errors in these assumptions are negligible when the estimated nucleotide substitution $(d)$ is small $[>0.1$; (Nei, 1987)], but have an increasingly large effect as $d$ increases, resulting in an underestimation of the distances and a corresponding decrease in accuracy. The distances between the symbionts in this study are large, approaching, and in some cases exceeding, the upper limit of accuracy for this method.

Differences in copy number are also a problem in the 16S RFLP analysis, because these differences represent differences in genome organization rather than actual sequence divergence. Including all fragments in an analysis between two samples with different copy numbers will overestimate the calculated divergence by inflating the denominator in the fraction of conserved hybridizing fragments. There is no valid way to normalize the data, but to test the robustness of our conclusions, we attempted a conservative compensation for copy number discrepancies by recalculating divergence with the denominator normalized to the smallest number of fragments in each sample pair. The values obtained by these calculations should be the lowest possible estimates of divergence within each pair. Using this method of estimation, the intergeneric divergences among the symbionts are not significantly changed [ranging from 0.112 to $>0.122$ (corrected) versus $>0.117$ to $>0.151$ (presented in Table III)] and still correspond to species level differences among the characterized specimens.
The number of symbiont samples examined in this study is sub-optimal, due to the difficulty and expense involved in obtaining specimens, but we have attempted to compensate for the small sample size. The large intergeneric differences among the anomalopid symbionts is supported by 17 independent comparisons, i.e., each symbiont sample compared to each sample from a different fish genus. Even if $P$. palpebratus $\# 2$ were excluded due to a possible gene rearrangement, there are still 15 independent comparisons in support of our conclusion.

Despite the limitations of the analysis, several conclusions can be drawn. First, the symbionts are obviously not the same species in all members of the family Anomalopidae. The differences are so extreme that even the largest possible estimates of variance cannot obscure them. This result stands in distinct contrast to all those symbioses in other fish light organs in which symbiont identity has been studied. In addition, no geographical connection between host location and symbiont species is apparent, implying that no significant genetic exchange occurs between symbionts from different hosts via free-living populations. Furthermore, the symbiont branching ordcr is consistent with the proposed sequence of evolution within the family Anomalopidae. Thus, at this level of analysis, the symbionts appear to have coevolved with the host fish. The large difference between $P$. palpebratus \#1 and \#2 could be due to a rearrangement or unrecognized difference in the host fishes. Finally, the apparent low copy number of the 16S rRNA operon in the symbionts may represent genetic adaptation to the light organ environment. In any case, the symbiont divergence observed in the association between these luminescent bacteria and the anomalopid fishes appears to be novel among previously characterized light organ symbioses.

\section{Acknowledgments}

We thank A. C. Arneson and the Department of Marine Sciences of the University of Puerto Rico for assistance in collecting $K$. alfredi, A. C. Arneson and P. Colin for the A. katoptron and $P$. palpebratus specimens, and the staff of the H. Steinitz Marine Biological Laboratory, Eilat, Israel, for the $P$. steinitzi sample. We are grateful to Dr. G. Wilson for help in obtaining and running the computer programs, and Dr. R. Rosson and B. Tebo for their helpful suggestions. We also thank Dr. R. Rosenblatt for his identification of the Photoblepharon specimens and critical reading of the manuscript. Thanks are also due to M. P. Quaranta for help in writing the distance estimation program. This research was funded by the Office of Naval Research, grant no. N00014-89-J-1742.

\section{Literature Cited}

Baumann, P., L. Baumann, S. S. Bang, and M. J. Woolkalis. 1980. Reevaluation of the taxonomy of Vibrio, Beneckea, and 
photobacterium: abolition of the genus Beneckea. Curr. Microbiol. 4: $127-132$.

Baumann, P., L. Baumann, and M. Mandel. 1971. Taxonomy of marine bacteria: the genus Benecka. J. Bacteriol. 107(1): 268-294.

Belas, R., A. Mileham, M. Simon, and M. Silverman, 1984. Transposon mutagenesis of Marine Vibrio spp. J. Bacteriol. 158(3): 890-896.

Bercovier, H., O. Kafri, and S. Sela. 1986. Mycobacteria possess a surprisingly small number of ribosomal RN $\Lambda$ genes in relation to the size of their genome. Biochem. Biophys. Res. Comm. 136(3): $1136-1141$

De Buyser, M. L., A. Morvan, F. Grimont, and N. El Solh. 1989. Characterization of Staphylococcus species by ribosomal RNA gene restriction patterns. J. Gen. Microbiol. 135: 989-999.

Denny T., M. N. Gilmour, and R. K. Selander. 1988. Genetic diversity and relationships of two pathovars of Pseudomonas syringae. J. Gen. Microbiol. 134: 1949-1960.

Ditta, G., S. Stanfield, D. Corgin, and D. R. Helinski. 1980. Broad host-range DNA cloning system for Gram-negative bacteria: construction of a gene bank of Rhizobium meliloti. Proc. Natl. Acad. Sci. USA 77: 7347-7357.

Fitzgerald, J. M. 1977. Classification of luminous bacteria from the light organ of the Australian pinecone fish, Cleidopus gloriamaris. Arch. Microbiol. 112: 153-156.

Franche, C., and G. Cohen-Bazire. 1987. Evolutionary divergence in the nif H.D.K. gene region among nine symbiotic Anabaena azollae and between Anabaena azollae and some free-living heterocystous cyanobacteria. Symbiosis 3: 159-178.

Gottlieb, P., and R. Rudner. 1985. Restriction site polymorphism of ribosomal ribonucleic acid gene sets in members of the genus Bacillus. Int. J. Sys. Bact. 35(3): 244-252.

Gourse, R. L., M. J. R. Stark, and A. E. Dalhberg. 1982. Site-directed mutagenesis of ribosomal RNA: construction and characterization of dclction mutants. J. Mol. Biol. 159: 397-416.

Grimont, F., and P. A. D. Grimont, 1986. Ribosomal ribonucleic acid gene restriction patterns as potential taxonomic tools. Ann. Inst. Pasteur/Microbiol. 137 B: 165-175.

Haygood, M. G. 1990. Relationship of the luminous bacterial symbiont of the Caribbean flashlight fish, Kryptophanaron alfredi (family Anomalopidae) to other luminous bacteria based on bacterial luciferase (luxA) genes. Arch. Microbiol. 154: 496-503.

Haygood, M. G., and D. H. Cohn. 1986. Luciferase genes cloned from the unculturable luminous bacteriod symbiont of the Caribbean flashlight fish, Kryptophanaron alfredi. Gene 45: 203-209.

Haygood, M. G., B. M. Tebo, and K. H. Nealson. 1984. Luminous bacteria of a monocentrid fish (Monocentris japonicus) and two anomalopid fishes (Photoblepharon palpebratus and Kryptophanaron alfredi): population sizes and growth within the light organs, and rates of release into the seawater. Mar. Biol. 78: 249-254.

Jinks-Robertson, S., R. Gourse, and M. Nomura. 1983. Expression of rRNA and tRNA genes in Escherichia coli: evidence for feedback regulation by products of rRNA operons. Cell 33: $865-876$.

Johnson, G. D., and R. H. Rosenblatt. 1988. Mechanisms of light organ occlusion in flashlight fishes, family Anomalopidae (Teleotei: Beryciformes), and the evolution of the group. Ann. Linnean Soc. Lond. 94: $65-96$.

Kessel, M. 1977. The ultrastructure of the relationship between the luminous organ of the teleost fish Photoblepharon palpebrartus and its symbiotic bacteria. Cytobiologie 15: 145-158.

Leis, J. M., and S. Bullock. 1986. The luminous cardinalfish Siphamia (Pisces, Apogonidae): Development of larvae and the luminous organ. Pp. 703-714 in Indo-Pacific Fish Biology: Proceedings of the Second International Conference on Indo-Pacific Fishes, R. A. T. Uyeno, T.
Taniuchi, and K. Matsuura, eds. Ichthyological Society of Japan, Tokyo.

Leisman, G., D. H. Cohn, and K. H. Nealson. 1980. Bacterial origin of luminescence in marine animals. Science 208: 1271-1273.

Lindblad, P., R. Haselkorn, B. Bergman, and S. A. Nierzwicki-Bauer. 1989. Comparison of DNA restriction fragment length polymorphisms of Nostoc strains in and from cycads. Arch. Microbiol. 152: 20-24.

Maniatis, T., E. F. Fritsch, and J. Sambrook. 1982. Molecular Cloning (A Laboratory Manual). Cold Spring Harbor Laboratory, New York. P. 447.

McCosker, J. E., and R. H. Rosenblatt. 1986. Notes of the biology, taxonomy, and distribution of flashlight fishes (Beryciformes: Anomalopidae). Japn. J. Ichthyol. 34(2): 157-163.

Nei, M. 1987. Molecular Evolutionary Biology. Columbia University Press, New York. Pp. 106-107.

Nei, M., and W. Li. 1979. Mathematical model for studying genetic variation in terms of restriction endonucleases. Proc. Natl. Acad. Sci. USA 76(10): 5269-5273.

Reichelt, J. L., and P. Baumann. 1973. Taxonomy of the marine, luminous bacteria. Arch. Mikrobiol. 94: 283-330.

Reichelt, J. L., K. Nealson, and J. W. Hastings. 1977. The specificity of symbiosis: pony fish and luminescent bacteria. Arch. Microbiol. 112: $157-161$.

Ruby, E. G., and K. H. Nealson. 1976. Symbiotic association of Photobacterium fischeri with the marine luminous fish Monocentris japonica: a model of symbiosis based on bacterial studies. Biol. Bull. 151: $574-586$.

Ruby, E. G., and K. H. Nealson. 1978. Seasonal changes in the species composition of luminous bacteria in nearshore seawater. Limnol. Oceanogr. 23(3): 530-533.

Ruby, E. G., and J. G. Morin. 1978. Specificity of symbiosis between decp-sea fishes and psychotrophic luminous bacteria. Deep-Sea Res. 25: $161-167$.

Saunders, N. A., T. G. Harrison, N. Kachwalla, and A. G. Taylor. 1988. Identification of species of the genus Legionella using a cloned rRNA gene from Legionella pneumophila. J. Gen. Microbiol. 134: 2363-2374.

Stanley, J., G. G. Brown, and D. P. S. Verma. 1985. Slow-growing Rhizobium japonicum comprises two highly divergent symbiotic types. J. Bacteriol. 163(1): 148-154.

Stull, T. L., J. J. LiPuma, and T. D. Edlind. 1988. A broad-spectrum probe for molccular cpidemiology of bacteria: ribosomal RNA. $J$. Infect. Dis. 157(2): 280-286.

Suzuki, Y., T. Mari, Y. Miyata, and T. Yamada. 1987. The number of ribosomal RNA genes in Mycobacterium lepraemurium. FEBS Lett. 44: 73-76.

Tsao, S. G. S., C. F. Brunk, and R. E. Pearlman. 1983. Iybridization of nucleic acids directly in agarose gels. Anal. Biochem. 131: 365372 .

Unterman, B. M., and P. Baumann. 1990. Partial characterization of the ribosomal RNA operons of the pea-aphid endosymbionts: evolutionary and physiological implications. Pp. 329-350 in Aphid-Plant Genotype Interactions, R. K. Campbell and R. D. Eikenbary, eds. Elsevier Press, New York.

Wei, S. L., and R. E. Young. 1989. Development of symbiotic bacterial bioluminescence in a nearshore cephalopod, Euprymna scolopes. Mar. Biol. 103: 541-546.

Yang, Y., L. Yeh, Y. Cao, L. Baumann, P. Baumann, J. Sung-en Tang, and B. Beaman. 1983. Characterization of marine luminous bacteria isolated off the coast of China and description of Vibrio orientalis sp. nov. Curr. Microbiol. 8: 95-100. 